\title{
Voices in the New Millenium. Shepherds in the Pela Mountains (Southwest of Soria. Central Spain)
}

\author{
Angel Paniagua \\ Spanish Council for Scientific Research, CSIC, Madrid, Spain \\ Email: angel.paniagua@csic.es
}

How to cite this paper: Paniagua, A. (2019). Voices in the New Millenium. Shepherds in the Pela Mountains (Southwest of Soria. Central Spain). Advances in Applied Sociology, 9, 551-568.

https://doi.org/10.4236/aasoci.2019.912040

Received: November 13, 2019

Accepted: December 1, 2019

Published: December 4, 2019

Copyright $\odot 2019$ by author(s) and Scientific Research Publishing Inc. This work is licensed under the Creative Commons Attribution International License (CC BY 4.0).

http://creativecommons.org/licenses/by/4.0/

\begin{abstract}
This paper analyzes the discourses and voices linked with the shepherd process of change. The disappearance of traditional shepherd has begun a sequence of transformations in the sheep livestock in the depopulated rural areas in central Spain. Mainly are changes associated with the organization of work, the size of flock and the management of rural space. These processes of change present different characteristics even in small rural areas. The methods are mainly qualitative based on semi-structured interviews and extensive presence in the research area. The case study is the Pela Mountains in Soria province. The results of qualitative analysis suggest a process of change in the management of sheep, mainly associated with the increase of flock of sheep, disappearance of the salaried shepherd and a process of individualization in the use of municipal space.
\end{abstract}

\section{Keywords}

Shepherd, Discourses, Qualitative Methods, Marginal Areas, Depopulation

\section{Introduction}

The shepherd of a rural community has constituted a social figure of remarkable permanence in the rural areas due to the traditional extensive nature of sheep farming. Since the last years of the twentieth century, this situation has been subject to a marked transformation due to the socio-economic dynamics of rural areas. At present, the shepherd constitutes a symbolic figure that can adequately exemplify the remarkable processes of change that have taken place in the depopulated rural communities and allows the analysis of new strategies on the traditional management of the depopulated space. The shepherd is an expression 
of "othering" within dominant social and cultural construction of rural life (Cloke, 1997), which amalgamates the constellation of images, experiences and emotions as a result of the cultures of we live in (Urbanik, 2012: p. 1).

In rural communities of central Spain, the figure of the shepherd was linked to a type of traditional mixed production, with a certain degree of self-consumption and not strictly commercial relations. The shepherd was the person in charge of the care of the livestock and the owner's trust, usually called the "owner", with which he established relationships that lasted a lifetime with varied considerations and obligations. In similar terms, the case of the shepherd of a rural community can be established, who took care of all the small herds and was paid jointly by all the neighbors who used his service. Until the decade of the fifties and sixties of the twentieth century, the shepherd constituted a singular figure of a certain socio-spatial relevance in the countryside, which originated a cultural organization with notable territorial nuances (Elías, 1989; Acosta, 2001; Palleruelo, 1991).

In the last three decades of the twentieth century, this model begins to change due to a multiplicity of factors among which stand out (Rodríguez \& Gómez-Sal, 1991): a simplification of the cultivation systems, the gradual disappearance of livestock farms, a wider range of labor options and a change of traditional labor relations, as well as a notable transformation of rural communities.

In recent years, various studies and journalistic information have revealed the transformation of the shepherds, including its possible extinction. In Spain, according to various estimates, there are about 80 - 90,000 shepherds and about sixteen million sheep. The decrease in the number of shepherds has given rise to journalistic headlines such as "the shepherds, in danger of extinction", but neither the official bodies nor the associations of farmers have clear figures (Montañes, 2019).

This transformation of human factors has influenced the management and characteristics of livestock farm. Several general works have highlighted this trend, mainly on census data. In this sense, it is necessary to mention the works of Sierra, 2003, Buxadé, 1998, Esteban, 1997, which point out important provincial variations, but also suggest possible differences at the micro space level. These studies point to the availability of labor as one of the main factors of evolution, together with other circumstances such as pasture resources or the situation of herds. In parallel, we are witnessing a revitalization and social appreciation of the sheep shepherd, including as a refuge for exurbanites. Two major phases can be established: the first until 1985-90, where the traditional shepherd continues, "of a lifetime". There was dissociation between the sheep farmer and the salaried shepherd. The traditional shepherd lived with a family constantly and they were shepherds who know the livestock. The shepherd-owner duality was very important. The system was based on the extensive nature of the activity: "for the sheep the more hours in the field the better, there was no worse wolf than the corral" (LUC, SEsteban, 4-2005). The second phase, which coincides with the disappearance of the traditional shepherd figure, generates two phenomena: the introduction of foreign shepherds and the appearance of the sheep 
farmer-shepherd who has a large livestock ranch of around 1000 sheep and tends to land fencing where the livestock graze. Profitability will be linked to the number of sheep, mechanization and fencing of the land. The cattle herder is usually also a farmer to take advantage of the fodder (Table 1).

The purpose of this research is to analyze the different discourses and strategies associated with the transformation process of the traditional shepherd and the emergence of new figures such as the shepherd-livestock farm and its reflection in the renewed management of marginal spaces (Cloke \& Little, 1997), as consequence of the changes in the depopulated and marginal rural areas in central Spain.

\section{Theoretical Background: New Social and Spatial Marginality in the Shepherd}

In the study of the shepherd and extensive grazing, multiple directions of research can be adopted: social and spatial marginality, new social groups and individualization, new roles and imaginaries and new animal geographies. Studies on extensive grazing highlight some of the debates associated with animal geographies and spatial marginality (Yarwood \& Evans, 1998, Holloway, 2019). Through extensive livestock activity, multiple human-non-human hybrid relationships that have characterized the new animal geographies are highlighted (Philo \& Wilbert, 2000, Whatmore, 2002, Bock \& Buller, 2013). It is also possible to deconstruct the actually chaotic construction of traditional marginal people (Cloke, 1997: p. 268), through the other shepherd in other marginal and depopulated spaces (the Pela Mountains). The confluence between animal welfare and socio-spatial marginality allows us to unite these two orientations of rural geography. Among the multiple hybrid relations that can be established include:

1) Human-nonhuman relationship. Extensive grazing is carried out in the field, it is difficult to establish livestock due to lack of profitability and animal welfare. Grazing integrates man with the flock, this can generate emotional bonds (Lorimer, 2008, Lorimer, Hodgetss, \& Barua, 2019, Little, 2008), but also a complete dedication of the shepherd in the service of livestock (Greenhough, 2010). Every day and for many hours. In extensive livestock there is a delicate balance between human welfare and animal welfare. In this hybrid relationship, animal welfare is increased the more hours the livestock remain in the field, but the living conditions of the shepherd, the human welfare, are worsened. Extensive

Table 1. Phases in the process of change of shepherd.

\begin{tabular}{lll}
\hline \multicolumn{1}{c}{ Traditional shepherd } & \multicolumn{1}{c}{ Change phase } & Livestock-Shepherd \\
\hline - Feeling of belonging to the area and & - Occasional/rotating shepherds. & \\
rural community. & - No identity with the area & ownership and grazing \\
- Livestock trusted person. Feeling of & - Socio-labor market rights & Trend to herd-housing \\
loyalty & - New livestock management & - Limitation of herd size \\
- Compensation in kind: home, food. & ideas & \\
- Mixed agriculture, small herds & & \\
Own elaboration.
\end{tabular}


grazing benefits animal welfare but requires the presence of man to manage the herd in the field, the main cause of the lack of relief and continuity in the activity. This harms the transmission of ancestral knowledge associated with the sheep shepherd and their knowledge of the place. The cultural dimension of the shepherd is based on his interaction with animals and space in its most human and intimate dimension, walking through the countryside (Whatmore, 2006). This would be the most classic hybrid relationship (Whatmore, 2002), suggests multiple relationships between man and animal of a sanitary, territorial, socioeconomic, emotional nature ... (Jones, 2000, Asdal, Druglitro, \& Hinchliffe, 2016, Luhrs, 2018). From a traditional starting point the shepherd with the livestock to the most recent one that expresses a balance or balance between the shephe$\mathrm{rd} /$ livestock rancher and the cattle.

2) Human-nonhuman-rural environment relationship. Extensive grazing is a traditional example of reconciling an agrarian activity with the surrounding environment. It may have low productivity, but it has a remarkable ability to use local natural resources in a sustainable way. Through here it is possible to establish dialogues between the open and (semi) close range and the biopolitics (Hodgetts, 2017, Jones, 2000, Laforge \& McLachlan, 2018) or between continuous space and segmented space. The analysis of extensive livestock helps dissolve the boundaries between animal and human and promote an "animal into nature" vision (Anderson, 1998, Lorimer \& Driessen, 2016, Lorimer, Hodgetss, $\&$ Barua, 2019).

3) Commoditization of shepherds. Currently, the activity of grazing presents interest to the urban consumer as highlighted by the tourist activities "being a shepherd for a day" or "being a shepherd for a few days" that consist of the accompaniment of a shepherd during his daily departure with the livestock or the accompaniment for several days in transhumance experiences in very depopulated areas (Carrasco, 2015). From this hybrid relationship it is possible to establish other multiple relationships between urban-rural and production-consumption categories (Jones, 2003). The shepherds transformation is produced by produce "experiences from within" (Cloke, 1997), but also by commoditization and marginality processes.

The analysis of the voices of the shepherds suggests two main research strategies: 1) the relationship between livestock and the sheep farmer/shepherd and 2) the transformation of the social position of the shepherd in the framework of the change of rural communities in central Spain.

\section{Methodology and Study Area}

Some rural geographical literature suggests the need for local geographic-based studies, so that certain marginal voices, such as shepherds, may be heard and biographical trajectories and emotional narratives can be described (Paniagua, 2017, Riley, 2010). Biographical studies based on narratives that have been used to study processes of spatial and rural marginalization and in the construction of otherness the shepherd, emphasize the relevance of location and representative- 
ness of the study area (Elwood \& Martin, 2000, Khosrobeigi, 2018). Only intensive qualitative research, based on selected cases, can adequately identify relationships and strategies of marginal groups and individuals (Cloke \& Johnston, 2005). To fill this research gap in rural studies, this contribution use qualitative methods with a biographical orientation approach to ethnographic interviews (Elwood \& Martin, 2000, Crang, 2007). Through this research method, the participant's professional experiences and their connection with feelings and moral values that establish their individual histories are able to be detailed (Hoggart, Lees, \& Davies, 2002, Hay, 2003, Wilson, 2017). With local narratives it is possible to include popular knowledge in public management and development programs and democratize the views of experts (Bixler, 2013).

Research design. This research was designed using qualitative methods able to analyze oral and biographical discourses of shepherds about rural change processes in local spaces (Riley \& Harvey, 2007). The use of qualitative techniques aims to establish different individual strategies between livestock farmers and, specifically through the own voice of the shepherd (Pickerill \& Chatterton, 2006). With this methodological design, the research carried out is of a qualitative and geo-ethnographic type, based on conducting semi-structured interviews (Dunn, 2003, Kopsel, Walsh \& Leyshon, 2017). In total, 26 in-depth interviews have been conducted with farmers and shepherds, with a variable duration between 45 minutes at two or three hours in spring 2005 (Table 2). The temporal distance adds value to the qualitative analysis by evidencing the situation at the turn of the millennium and giving it an unrepeatable and geo-historical character (Williams \& Riley, 2018). The interview script has different parts: the first one referring to their personal situation (age, marital status, family, place of birth), the second one related to the management of the livestock farm and the beginning in the activity ( size of the herd, time of daily dedication, year of entry into activity, number of people working in the livestock farm), the third one related to the space-time organization (off-site travel, reason for travel) and the fourth one intended to warn the perception social and self-perception of their profession (relationship with the rural community, professional self-consideration). In parallel, each respondent fills in a questionnaire, with results previously addressed that acquire statistical significance (Paniagua, 2006 and 2007). In certain singular cases, qualitative research was completed with the accompaniment of the shepherd-farmer in the work of grazing, to share and witness their spatial patterns and routines in the management of livestock (Riley, 2010).

In addition, there have been 4 interviews with key informants among veterinarians in the area that allow contextualizing the information received and 4 interviews with retired traditional shepherds or still active on changes in the profession. This methodology is intended to show how the evolution of the traditional shepherd and its gradual extinction stimulates the transformation of livestock activity.

Study area. The geographical area of the southwest of the province of Soria 
Table 2. Municipal distribution of interviews conducted in spring 2005.

\begin{tabular}{|c|c|c|}
\hline $\begin{array}{c}\text { Number of livestock } \\
\text { interviews }\end{array}$ & Municipality & $\begin{array}{l}\text { Number of veterinary, technical and } \\
\text { (traditional shepherds) interviews }\end{array}$ \\
\hline \multirow[t]{2}{*}{1} & Atauta & \\
\hline & Burgo de Osma & 1 \\
\hline 1 & Carrascosa de Arriba & \\
\hline 2 & Cuevas de Ayllón & \\
\hline 1 & Fuentecambron & \\
\hline 1 & Hoz de Abajo & \\
\hline 2 & Langa de Duero & \\
\hline 1 & Liceras & \\
\hline 1 & Ligos & \\
\hline 1 & Losana & \\
\hline 1 & Lumias & \\
\hline 1 & Manzanares & \\
\hline 2 & Montejo de Tiermes & (1) \\
\hline 1 & Nograles & \\
\hline 1 & Noviales & \\
\hline 1 & Pedro & \\
\hline 1 & Peralejo & \\
\hline 1 & Rejas & \\
\hline 2 & San Esteban de Gormaz & $3(2)$ \\
\hline 1 & Tarancueña & \\
\hline 1 & Torremocha de Ayllón & \\
\hline 1 & Valderroman & \\
\hline 1 & Valdonzuelo & \\
\hline 26 & TOTAL & $4(3)$ \\
\hline
\end{tabular}

Own elaboration.

has different characteristics that give it a singular value: it is a traditional area of extensive sheep grazing, -a native breed, the "ojalada” sheep (Sánchez \& Sánchez, 1986), is an area extremely depopulated and sheep management currently has a significant influence on space management (Bedotti et al., 2005). This area constitutes an adequate example of the social transformation of the shepherd profession in rural communities of depopulated areas of central Spain. This area corresponds to the natural region of the Sierra de Pela (San Esteban de Gormaz, Soria) (Figure 1). Within this area the study has focused on the southern natural sub-region, adjacent to the provinces of Segovia and Guadalajara, one of the most depopulated areas of Spain and Europe. In this area, space management continues in the hands of shepherds and sheep farmers. 


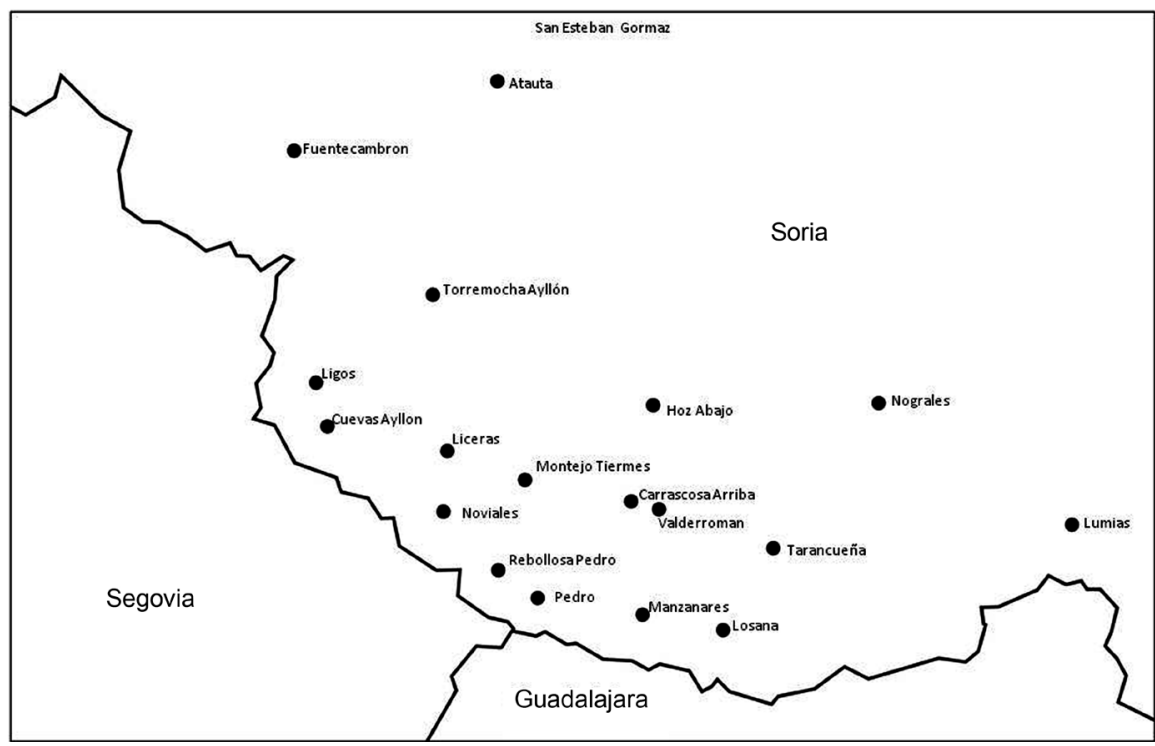

Figure 1. Research area. Pela mountains.

\section{The Analysis of New Shepherds: Characteristics, Feelings, Personal Speeches and Space Biographies}

Shepherds are a heterogeneous group due to the diversity of professional situations and their main personal characteristics even at a micro-scale level of analysis.

The personal and family characteristics of shepherds suggest a certain disparity in their age and a clear masculinity. The woman, when she participates in the tasks of the livestock farm, does so in times of greater work or in management and commercialization tasks. But, it even seems a matter of solvency and professional prestige that women do not participate in the work with livestock. The members of the family group have a specialization: women in the domestic sphere and men with livestock and agriculture. This organization connects with the need to dissociate the family and professional environment. "Women do not want this" (G.M. Hoz de Abajo, 5-2005), is a common phrase.

There are different types of family, but more than half of the livestock farmers are married and have families, four out of ten remain single and punctually divorced or separated shepherds appear. Among married people more than half have two or more children. The existence of children cannot be seen from the traditional perspective of complement of work in sheep farmers due to the feelings of rejection on the part of the children towards the father's livestock activity: "I would enjoy if all the sheep died" (AMP Liceras, 5-2005). This emotional judgment causes problems in the succession of new shepherds.

Feelings. A feeling that usually appears among respondents is loneliness. But this feeling is manifested both among the shepherds with family and among those who live alone. The feeling of loneliness is produced by the characteristics of the profession and its location in depopulated areas: "Now I get bored more than before. Before he slept with the sheep. Now it is becoming less" (AMP, Li- 
ceras, 5-2005). Also the feeling of loneliness appears in relation to the non-existent replacement for the development of the activity in case of illness. Professional loneliness is often associated with "a certain burden for the need to tell problems" (JYJ, Nograles, 5-2005). In some cases "loneliness depends on health and if it is a danger for the care of livestock" (JYJ, Nograles, 5-2005). On the other hand, livestock farmers are also frequent who indicate that they are single or that they have divorced for the activity. Other feelings that usually appear are: 1) "the taste" for living in a rural environment; 2) personal and professional freedom associated with biography.

Spatial Biography. The place of residence coincides with that of birth in seven out of ten cases. This low geographical mobility is linked at the beginning in the activity by family or geographical tradition and influences spatial and social identity, a common feature in shepherds from other regions (Paniagua, 2013). Due to the early biographical start in grazing activity as a "zagal" a young shepherd-, most have basic studies, but there are also singular cases of university students returning to the area due to maladjustment or lack of opportunities in the city or the desire to modernize the agrarian inherited land. Those who come from abroad point out "I came from nowhere and based on work has not lacked to eat and has not left over" (PSS, Peralejo, 5-2005).

\section{How to Become a Shepherd: A Life, a Feeling and Family Tradition}

How to become a shepherd is a complex process, but that is traditionally dominated by personal biography. The biography itself determines the permanence in the activity.

Rural society in depopulated areas can respond more to individuals dynamics than of social groups (Paniagua, 2017). Among the shepherd the biography has a remarkable weight and the beginning in the activity takes place for reasons of family type. They are conditioned to create their own biography by the weight of family tradition (Gray, 1998). In many cases the father and grandfather had the same activity and with their retirement inherit the sheep farm. This form of start in the activity is considered very relevant by all shepherds, who warn that grazing is felt and transmitted. It is not only necessary to have knowledge of the care of livestock, but also of the environment. When the start of the activity occurs later, it is due to processes of return due to maladjustment to the city. In any case, it is considered very difficult for someone who comes from the city or other trades to succeed in sheep farming.

There are three modalities of beginning in the activity: 1) Hereditary and traditional, it is the majority, they began between 12 and 15 years in the activity as "zagales" with their father or a relative, until they inherited the livestock farm, without having known another job, neither want it nor look for it. They would not know what to do with their lives outside the livestock activity. It is the majority group. Grazing is a way of life. It is necessary to consider that three out of 
four livestock farmers have been in the activity for more than 15 years and that the average year of beginning in the activity was 1980 and that of the establishment of the livestock farm was 1965, which suggests its hereditary character. It is now recognized that "new generations are the ones that have less interest in sheep. The sheep demand dedication every day" (ATP, Atauta, 4-2005) 2) Resistance-resilience, the livestock activity is continued using the minimum time and combining it with other activities. The expectation of change and abandonment of the activities is permanent, mainly due to the lack of schedules and the difficulties in achieving the economic viability of livestock: "Nobody wants it, but now gives more money than nothing" (RPP, Langa, 5-2005). 3) Returned from the city who, due to social and labor maladjustment, returns to their parents' trade. It is a very minority group. The sentence "you are not under anyone or anything" (FRM, Fuentecambrón, 5-2005) highlights the sense of self-management and individual freedom of grazing.

In the following sections different aspects that influence the professional activity and community life of the shepherds are analyzed. It is intended to give a global vision of the life and activity of shepherds.

\section{Place Use}

The progressive disappearance of shepherds as a person of confidence in livestock management has already been noted: "It assists a process of extinction of the shepherds. They were usually from a poor family, including the village short (...), now from the village short; it is passed to people from Eastern, Moroccan countries. The shepherd"s life is hard" (JyS, SEsteban, 4-2005). This has led to various strategies in livestock activity with spatial impact. "Most of the farms end up with these traditional shepherds, only the most specialized ones with more than 1000 sheep survive" (JYS, SEsteban, 4-2005). The main transformation has been the assimilation of grazing by the owner of the livestock, who is usually also a farmer, to constitute a new socio-economic figure that could be called a shepherd-livestock farmer who integrates the property of livestock, their daily care and grazing. "Now almost all farmers combine grazing with agriculture" (MAR, SEsteban, 4-2005).

In most cases, the retirement of the "trusted" or "lifelong" shepherds leads to the elimination of the figure of the shepherd, replaced in his work by the owner of the livestock: "You can't have a shepherd, he takes everything and they don't know anything, before I sell them to take shepherd or confine them" (DYC, Tarancueña, 5-2005). In this way, the traditional salaried shepherd tends to disappear: "My father had livestock farmer with three traditional shepherds. That generation of shepherds is over, now we have no shepherds. Now my brother attends the farrowing and the cattle are semi-stable" (ATM, Atauta, 4-2005). Instead, there are occasional shepherds, often detached from the area, undervalued socially and professionally and that many times the livestock farmers themselves qualify as "skyrocketing", to highlight their lack of professional qualification. On 
the other hand, the modern labor regulation of the activity of the shepherds makes impossible the development of his profession as has been traditionally understood ("in the end you work for the shepherd"). A shepherd suggests that "now shepherds are bad, with little preparation and many parties" (VC, Carrascosa, 5-2005). The importance of the shepherd is due to the fact that the least cost is to feed the livestock in the field. "To establish more prices is needed, in order to find profitability. Extensive cattle are always linked to the environment, grass is spontaneous and you depend on people, but it is always more profitable" (JE, Valdonzuelo, 5-2005).

One of the most immediate consequences of these changes is the establishment of new formulas for grazing development and livestock and space management, even at the micro level. That is, there are contrasted types in relatively small spaces such as a sub-region or even a municipality, according to the personal or family characteristics of the farmer and his farm. It would be possible to distinguish four great speeches, with multiple nuances attached to the place: 1) A purely business strategy, associated with a gradual reduction and de-utilization of space and stabling or semi-stabilization of the herd, through fences. This space management is linked to a notable increase in the size of the herds, which far exceed 1000 sheep, with the employment of various people. "My father had cattle and three traditional shepherds. That generation of shepherds is over, now we have no shepherds (...). For 8 years we have no shepherds who have come or are based on deception or unskilled. For 5 or 6 years the cattle have been semi-sheltered" (ATP, Atauta, 4-2005). It is a minority strategy, but with a leadership position (Lavín, et al., 2000).

2) Individualist-traditionalist-animalist linked to an individual shepherd-owner, who develops his activity alone and acquires the grazing rights of his entire municipal term. It is the exponent of a process of business and spatial individualization that occurs in the most depopulated areas, where the farmer-shepherd is the main social support of the population in winter. It involves the use of the municipality by a single flock. There is a certain idyll in the management of space and in the way of life, which goes beyond the strict business strategy. "The shepherd is something that is born with it, it is a way of life (...) the shepherd's life is associated with the feeling of freedom, but not spatial freedom, but personal freedom" (JI, Pedro, 4-2005). It is a third of the cases, but it is the dominant trend in the most depopulated areas, with little competition from any other activity, except for hunting and partially agriculture. In general, the tendency to a single livestock farmer by municipal term facilitates the management of livestock, since there is no space competition with other farmers. This orientation is the result of retirement processes, abandonment or purchase of the herd and rights to other shepherds. In this way, the space management limit is usually associated with the territorial limit of the municipality. The municipal space constitutes the limit in the personal and business goal of the livestock farmer, which culminates in the control of the rights of pastures of the municipality; it constitutes your particular world. 
3) Family community linked to the distribution of business and spatial functions (grazing) among the different components of the family group. It occurs when two or more brothers have ownership and management of the herd. "We are from here, parents and grandparents too. We started at age 11 and we have only been farmers (...). We are the only livestock farmers, the whole term is ours (the rights of the CAP) (...) we work for two salaries" (DYC, Tarancueña, 5-2005). This is the dominant model and allows replacing the disappearance of the traditional shepherd. It is also the most vulnerable model when one of the components of the family group leaves the activity.

4) In expectation of withdrawal, characterized by a gradual decrease in the heads of livestock and the secondary nature of the economic reasons for continuing activity. In some cases continuing with the livestock activity is associated with the vital sense of existence or a hobby (Riley, 2011). As a livestock farmer indicates "the continuity for the livestock, the boys were not situated and for defending them" (VC, Carrascosa, 5-2005).

In any case, it is necessary to indicate a remarkable spatial identity, based on the place of birth, life and management of the livestock activity.

\section{Time and Mobility}

Grazing means ample time dedication. This is the most negative factor of the activity itself and the one that causes the most dropouts. The sheep shepherd imposes a remarkable dedication, absolute for many. Even so, an improvement in working conditions is also recognized. In any case, the profession is associated with a figurative "slavery", given the absence of weekends, holidays ..., which prevents a normal social life. 'Here you put more hours than a clock' (GM, Sickle, 5-2005). The tranquility of the place and the pleasure of living in the town are also valued. The activity is associated with negative attributes or symbols such as hardness, burden, slavery, monotony. "It is a very slave job, but we have nothing else, we have invested everything we have earned, sheep every day" (DYC, Tarancueña, 5-2005). Others indicate "work, from sun to sun, even parties, but liking it well, for the joy of seeing cattle" (RBM, Cuevas, 5-2005). Usually one day is distributed between the walk with the flock of sheep for about 4 to 6 hours following previously established itineraries for the best feeding of livestock (an average of 6 to 8 kilometers are traveled) and another 4 to 6 hours dedicated to the other works, with a greater tendency to housing the sheep in the winter. There are also variations according to the strategy that is followed in the exploitation. Each livestock farmer tends to group the livestock burden of a single municipality. The activity itself favors individual strategies, but it is recognized that "the most enemy can get you out of a well or a ravine" (GM, Sickle, 5-2005), pointing to certain bonds of solidarity in extreme situations. Loneliness is associated with health that influences the care of livestock and the lack of social life. "Dogs are my family, when one dies, I'm very sorry" (JYJ, Nograles, 5-2005). Others establish emotional ties with the cattle, "not seeing the cattle in 
good health, I don't die a sheep by abandonment" (PSS, Peralejo, 5-2005).

\section{CAP and Agri-Environmental Regulation}

As indicated, the main problem facing the shepherd-livestock farmer is the wide working hours. Another aspect that limits the livestock activity is the competence of agri-environmental measures and diverse hunting and flora regulations. Agri-environmental measures in depopulated areas change the traditional use of space and make grazing more complex. The CAP favors farmers. Expressions such as "it is necessary to go out with a map" or "this is a mosaic" highlight the difficulties for the conduction of livestock, so there is a tendency towards concentration in areas where agricultural activity has virtually disappeared or they are outside the areas delimited for the execution of agri-environmental measures. The environmental set-aside generates conflicts: "agri-environmental measures are a mess, it makes the quarrels of villages and the clashes between livestock farmers and agricultural farmers emerge" (RPR, Langa, 5-2005). This factor also induces semi-housing of livestock: "With the agri-environmental measures, it will go to semi-sheltered livestock" (AMP, Liceras, 5-2005). Now he spends less time with the sheep, before he even slept with them.

There is a remarkable moral dilemma about the good farmer or livestock farmer (Holloway, 2002), the one who takes care of his cattle and obtains profitability. With the current aid system of the CAP, it is felt that the good farmer is not rewarded, which obtains yield and production. Prices are very low and public subsidies equate good and bad livestock. "Before a farmer became rich, now it doesn't matter if he is good or bad" (JYJ, Nograles, 5-2005). It is necessary to stimulate the production and care of livestock. The CAP is a "candy in the mouth", but prices are low (VC, Carrascosa, 5-2005). Other farmers even indicate that "the livestock premium, the best to remove it, does not favor professional farmers, favors bad farmers" (DYC, Tarancueña, 5-2005). In this sense, it is indicated that the aid of the CAP should be only for professional farmers, since it is stated that "the assistance of the CAP to buy apartments that is not the field, the field must be improved. A balance between afforestation, hunting and agriculture is necessary and consequently we must have the professionals of the field" (JF, Grilles, 5-2005). For other farmers "it is necessary, the market has been the same for many years" (JYJ, Nograles, 5-2005) or "the CAP is an aid that is needed to continue, this is a desert and some help is needed" (DOM, Caves, 5-2005). Even so, abuses are recognized, since poor quality livestock are acquired with the sole purpose of collecting subsidies. A good feeding of the livestock and their correct attention are characteristics of the good livestock farmer. "What you may have but well attended" (DOM, Cuevas, 5-2005). In this way, even some point to the non-continuity of the livestock premium "I would bet on non-continuity, since it can influence the care of animals" (JAC, Valderroman, 5-2005). A livestock farmer summarizes the situation with the following sentence: "The livestock premium should not be, better real price, but without a 
premium could not be followed" (JJMS, Langa, 4-2005). Among livestock farmers not born in the area with a resistance strategy, they indicate that "the subsidy holds us down" (PSS, Peralejo, 5-2005).

The CAP generates two unwanted processes in extensive livestock: 1) traditionally extensive livestock is a territorially sustainable activity integrated in traditional and conventional agriculture. With the introduction of environmental regulations in agriculture, this relationship is broken and difficulties for traditional grazing begin. Agri-environmental regulation competes with extensive spatially sustainable livestock. 2) The regulation of the CAP breaks the moral principle of a good farmer, the one who took care of his cattle and obtained the best possible performance. It favors the appearance of farmers who have sheep to obtain subsidies and consequently breaks the traditional balance of livestock with the environment.

\section{Mobility out of Place}

Mobility is reduced, but greater among owners of larger farms and with several people because there can be a rotation. Normally the displacements occur towards the commercial centers of the region, with a weekly or fortnightly periodicity. Displacements strictly for leisure to major urban centers are more sporadic and one in three livestock farmers never travel to other sites. "It is a slave job; there are no Saturdays or Sundays. We don't go out, we never go anywhere" (AMP, Liceras, 5-2005). As indicated by a livestock shepherd who has never left town: "I went to Madrid once in the 60s to my brother's house, 15 days and drowned. My brother didn't have time to eat, always in a hurry" (PCA, Lumias, 5-2005). "The field is freedom against the capital where everything is done running" (AMP, Liceras, 5-2005). Others value life in the town for tranquility, low density and associate life in the city with traffic and noise. "I didn't like the city, everybody doesn't like the city. In the town there is tranquility, it is like my life, nobody bothers you, you know everyone" (UL, Montejo, 5-2005). Others who have had biographical experiences in the city state that "Madrid did not enter me, I saw myself locked up, I need to see field" (PSS, Peralejo, 5-2005). Others associate the city with vice: "I do not go to the city, when you return you come full of alcohol” (RMV, Torremocha, 5-2005).

\section{Spatial and Professional Identity}

Traditionally, the figure of the shepherd is associated with the lower social groups of the rural community. It was a job opportunity for people with low expectations in other activities. The transformations of their activity make their social self-perception positive, especially among those originating from the place. Among the factors that explain this social location are: the autonomous nature and environmental benefits of the activity, membership in associations and the number of people working in relation to the herd (Izquierdo \& Barreda, 2006). In other words, social self-assessment is linked to socio-geographical factors of identity with the place, as well as to new economic or labor factors. It is 
also possible to consider other factors such as marital status or the obtaining of economic income equivalent to those they would receive in urban areas. It is also interesting to indicate that most livestock farmers dissociate their own position from the shepherd, which they see as a profession of low value. The livestock activity traditionally has a good economic valuation: "In this area (...) the one that has had cattle has had money, now it is a profession, the big farms remain" (SAL, Manzanares, 5-2005). Many indicate that they are dedicated to livestock "for pleasure, it is like a drug; I want to have more sheep" (FRM, Fuentecambrón, 5-2005). Others suggest that "born with it, is a way of life" (JI, Pedro, 4-2005), based on personal, spatial and business freedom. "I have not worked for anyone in my life; I value freedom a lot, to do what I want ..." (JJMS, Langa, 4-2005). Livestock work is increasingly individualistic: "this is your life, improving it is itching; you have satisfaction when you meet expectations" (SAL, Manzanares, 5-2005). The tendency is a single shepherd-farmer by municipal term and by town. "The farmer wants freedom and the farmer does not leave him" (JI, Pedro, 4-2005), in relation to mobility for the municipality and the existence of crops. "If I could with my economic means nobody would work, I would fence the term and leave the term to me, but the farmer entered before me" (JI, Pedro, 4-2005).

All shepherds have a precise image and knowledge of everyday space and in most cases they carry out tasks for their care or improvement (Christie et al., 2004). "Now the sheep is a business that takes root; you also like, by the field, the animals, the grazing itself" (RP, Losana, 5-2005). Even the traditional managers or stewardship of the environment are self-considered. In their entirety they express that they perform environmental services not paid to the local community or society. "When it is not grazed, there would not be a healthy mountain, grazing is necessary to keep the mountain healthy" (JE, Valdonzuelo, 5-2005). Therefore there is a clear awareness of the activity of grazing to the care of nature, which confronts with the agri-environmental measures that hinder its activity. "Due to the sectoral evolution (...) there is a loss of environmental services in the municipality; I am in favor of the subsidy to perform these traditional tasks" (ATP, Atauta, 4-2005). The developments of environmental services agree with a perception of the environment as an integrated system, in which landmarks such as rivers or singular forest stands stand out. The positive appreciation of the profession is enhanced by the association of nature or the field with values such as freedom or tranquility. In contrast, a negative assessment of the urban environment is carried out, especially among returned peoples.

Finally, although the continuity of the activity is safe for most shepherds, the vision of the future is not optimistic because of the hardness of the trade, especially among those who shepherd alone.

\section{Relationship with Seasonal Residents, Visitors and Those Who Left}

A usual discourse among the sheep livestock is the differences by the manage- 
ment of the municipal territory with which they left and return seasonally to the town, expressed in multiple ways: "You have problems with people who come the weekend. Those of the exodus return and say that they have benefited from those who left" (AMP, Liceras, 5-2005). Or with "the children of the town, some kind of a shame, since they left and identify our prosperity with their march, we manage the entire municipal term" (JYJ, Nograles, 5-2005). In this sense it is also indicated, "the children of the village think that we have eaten the whole term for us" (DOM, Cuevas, 5-2005). Another farmer points to a certain nuance: "On the one hand they think you live because they are gone. That you have appropriated what they leave, on the other hand, think that you are doing a service to keep it populated and avoid looting" (RP, Losana, 5-2005). Others simply suggest that "emigration has allowed dignified living in the villages" (RPP, Langa, 5-2005).

In some cases there are complaints about people of alternative life: "Some anarchists who have lived for 8 years and say there is no private property" (SAL, Manzanares, 5-2005). Some livestock farmer in a more generic way indicates "the people of the city to destroy" (JF, Grilles, 5-2005).

\section{Conclusion}

The social figure of the shepherd is emblematic in the rural areas. Its evolution symbolizes the processes of change in the rural areas of central Spain, especially among its lower socioeconomic groups. As Cloke (1997) suggests, it is the "experiences from within" that produce the transformation of livestock activity. The progressive disappearance of the traditional shepherd has led to the emergence of new socio-economic figures that encompass livestock grazing activity and livestock ownership. This new situation is characterized by heterogeneity in the organization of livestock, grazing and work. But, the main characteristics are the notable differences of the socioeconomic and territorial strategies, even in small spaces. Livestock management and space use have a tendency to individualize. The livestock farmer has values that attach great importance to freedom, autonomy ... In the work area it is possible to distinguish several orientations: shepherds from outside the area, shepherds with business training, community of goods between family members where one specializes in sheepherding or the association between two brothers or traditional shepherds.

The animality and marginality of shepherds suggest a social co-evolution. In the balance between animal and human well-being, there is a clear orientation to reduce grazing time and to limit the space where "livestock" walks, in order to reduce extensive dedication to livestock and improve their quality of life. These modifications suggest a change in their traditional role of the "other" in rural communities. The role of stewardship of livestock is joined by the owner of livestock, farmland and agricultural infrastructure. This modification in the role of stewardship of livestock is accompanied by a change in the social position within the community, from the traditional position of "other". In some cases 
they reach leadership positions: mayors or union leaders.

\section{Conflicts of Interest}

The author declares no conflicts of interest regarding the publication of this paper.

\section{References}

Acosta, R. (2001). Memoria de la tierra, campos de la memoria. Los agroecosistemas tradicionales de Tentudía. Tentudía: Centro comarcal.

Anderson, K. (1998). Animals, Science, and Spectacle in the City. In J. Wolch, \& J. Emel (Eds.), Animal Geographies: Place, Politics, and Identity in the Nature-Culture Bordelands (pp. 27-50). London: Verso.

Asdal, K., Druglitro, T., \& Hinchliffe, S. (2016). Human, Animals and Biopolitics. The More-Than Human Condition. London: Routledge. https://doi.org/10.4324/9781315587639

Bedotti, D., Gómez Castro, A. G. et al. (2005). Aspectos sociológicos de los sistemas de producción caprina en el oeste pampeano (Argentina). Archivos de Zootecnia, 54, 599-608.

Bixler, P. (2013). The Political Ecology of Local Environment Narratives: Power, Knowledge, and Mountain Caribou Conservation. Journal of Political Ecology, 20, 273-285. https://doi.org/10.2458/v20i1.21749

Bock, B., \& Buller, H. J. (2013). Healthy, Happy and Humane: Evidence in Farm Animal Welfare Policy. Sociologia Ruralis, 53, 390-411. https://doi.org/10.1111/soru.12011

Buxadé, C. (1998). Ovino de carne: Aspectos clave. Madrid: Mundiprensa.

Carrasco, E. (2015). Ser pastor por unos días en Soria. https://www.rutaenfamilia.com/ser-pastor-por-unos-dias-en-soria/

Christie, N. et al. (2004). Manolo's World: Peopling the Recent Past in the Serra de l'Almirant. Leicester: University of Leicester.

Cloke, P. (1997). Poor country. Marginalisation, Poverty and Rurality. In P. Cloke, \& J. Little (Eds.), Contested Countryside Cultures (pp. 252-271). London: Routledge.

Cloke, P., \& Little, J. (1997). Conclusion. Marginality and Rural Others. In P. Cloke, \& J. Little (Eds.), Contested Countryside Cultures (pp. 272-284). London: Routledge.

Crang, M. A. (2007). Doing Ethnographies. London: Sage. https://doi.org/10.4135/9781849208949

Dunn, K. (2003). Interviewing. In I. Hay (Ed.), Qualitative Research Methods in Human Geography (pp. 50-82). Oxford: Oxford University Press.

Elwood, S. A., \& Martin, D. G. (2000). "Placing” Interviews: Location and Scales of Power in Qualitative Research. The Professional Geographer, 52, 649-657.

https://doi.org/10.1111/0033-0124.00253

Esteban, C. (1997). El ganado ovino y caprino en el área de la Unión Europea y en el Mundo. Madrid: MAPA.

Gray, J. (1998). Family Farms in the Scottish Borders: A Practical Definition by Hill Sheep Farmers. Journal of Rural Studies, 14, 341-356. https://doi.org/10.1016/S0743-0167(98)00010-2

Greenhough, B. (2010). Vitalist Geographies: Life and the More-Than-Human. In B. Anderson, \& P. Harrison (Eds.), Taking-Place: Non Representational Theories and Geo- 
graphy (pp. 37-54). London: Ashgate.

Hay, I. (2003). Qualitative Research Methods in Human Geography. Oxford: Oxford University Press.

Hodgetts, T. (2017). Wildlife Conservation, Multiple Biopolitics and Animal Subjectification: Three Mammals' Tales. Geoforum, 79, 17-25. https://doi.org/10.1016/j.geoforum.2016.12.003

Hoggart, K., Lees, L., \& Davies, A. (2002). Researching Human Geography. London: Arnold.

Holloway, L. (2002). Smallholding, Hobby-Farming, and Commercial Farming: Ethical Identities and the Production of Farming Spaces. Environment and Planning A, 34, 2055-2070. https://doi.org/10.1068/a34261

Holloway, L. (2019). Smallholder Knowledge-Practices and Smallholding Animals: Threats or Alternatives to Agricultural Biosecurity? Journal of Rural Studies, 69, 19-29. https://doi.org/10.1016/j.jrurstud.2019.04.013

Izquierdo, J., \& Barreda, G. (2006). Marqueses, funcionarios, políticos y pastores. Crónica de un siglo de desencuentros entre naturaleza y cultura en los Picos de Europa. Oviedo: Nobel.

Jones, O. (2000). (Un)ethical Geographies of Human-Non-Human Relations: Encounter, Collectives and Spaces. In C. Philo, \& C. Wilbert (Eds.), Animal Spaces, Beastly Places (pp. 268-292). London: Routledge.

Jones, O. (2003). 'The Restraint of Beast': Rurality, Animality, Actor Network Theory and Dwelling. In P. Cloke (Ed.), Country Visions (pp. 283-307). London: Pearson.

Khosrobeigi, R. (2018). Gender Identities and Farm Survival: Women's Activities in the Agricultural Sector in Remote Rural Areas. Corvinus Journal of Sociology and Social Policy, 9, 77-98. https://doi.org/10.14267/CJSSP.2018.2.04

Kopsel, V., Walsh, C., \& Leyshon, C. (2017). Landscape Narratives in Practice: Implications for Climate Change Adaptation. The Geographical Journal, 183, 175-186. https://doi.org/10.1111/geoj.12203

Laforge, J., \& McLachlan, S. (2018). Environmentality on the Canadian Prairies: Settler-Farmer Subjectivities and Agri-Environmental Objects. Antipode, 50, 359-383. https://doi.org/10.1111/anti.12362

Lavín, P., Mantecón, A. R., \& Giráldez, F. J. (2000). Sistemas de pastoreo y utilización del territorio. Ovis, 74, 11-29.

Little, J. (2008). Nature, Fear and Rurality. In R. Pain, \& J. Smith (Eds.), Fear: Critical Geopolitics and Everyday Life (pp. 87-97). Abdington: Ashgate.

Lorimer, J. (2008). Charismatic Natures. In R. Kitchin, \& N. Thrift (Eds.), International Encyclopedia of Human Geography, (pp. 324-330). Amsterdam: Elsevier. https://doi.org/10.1016/B978-008044910-4.00560-5

Lorimer, J., \& Driessen, C. (2016). From 'Nazi Cows' to Cosmopolitan 'Ecological Engineers': Specifying Rewilding through a History of Heck Cattle. Annals of the American Association of Geographers, 106, 631-652. https://doi.org/10.1080/00045608.2015.1115332

Lorimer, J., Hodgetss, T., \& Barua, M. (2019). Animals' Atmospheres. Progress in Human Geography, 43, 26-45. https://doi.org/10.1177/0309132517731254

Luhrs, D. (2018). Australia's Family Farms and Farming Communities: Interdependent, Reconstituted, Threatened Spaces. Journal of Rural Studies, 62, 77-86. https://doi.org/10.1016/j.jrurstud.2018.07.005 
Montañes, E. et al. (2019). Los últimos pastores del campo español. https://www.abc.es/sociedad/abci-ultimos-pastores-campo-espanol-201902260216 not icia.html

Palleruelo, S. (1991). Pastores del Pirineo. Método y gentes. In L. V. Elias (Ed), Sobre cultura pastoral (pp. 283-299). Madrid: Centro de Investigación and Animación Etnográfica.

Paniagua, A. (2006). La nueva figura del pastor propietario en las áreas rurales despobladas. Revista de Ganadería, 38, 20-25.

Paniagua, A. (2007). Shepherd and Owners of Sheep in the Southwest of Soria. An Interpretation for Depopulated Areas. AZ Archivos de Zootecnia, 56, 839-849.

Paniagua, A. (2013). Farmers in Remote Rural Areas: The Worth of Permanence in the Place. Land Use Policy, 35, 1-7. https://doi.org/10.1016/j.landusepol.2013.04.017

Paniagua, A. (2017). Spatial and Individual Resistance(s) in Depopulated and Remote Rural Areas. Space and Polity, 21, 303-317. https://doi.org/10.1080/13562576.2017.1355874

Philo, C., \& Wilbert, C. (2000). Animal Spaces, Beastly Places. An Introduction. In Animal Spaces, Beastly Places. New Geographies of Human-Animal Relations. (pp. 1-34). London: Routledge.

Pickerill, J., \& Chatterton, P. (2006). Notes towards Autonomous Geographies: Creation, Resistance and Self-Management as Survival Tactics. Progress in Human Geography, 30, 730-746. https://doi.org/10.1177/0309132506071516

Riley, M. (2010). Emplacing the Research Encounter: Exploring Farm Life Histories. Qualitative Inquiry, 16, 651-662. https://doi.org/10.1177/1077800410374029

Riley, M. (2011). 'Letting Them Go'-Agricultural Retirement and Human-Livestock Relations. Geoforum, 42, 16-27. https://doi.org/10.1016/j.geoforum.2010.08.004

Riley, M., \& Harvey, D. (2007). Oral Histories, Farm Practice and Uncovering Meaning in the Countryside. Social and Cultural Geography, 8, 391-415.

https://doi.org/10.1080/14649360701488823

Rodríguez Pascual, M. A., \& Gómez Sal, A. (1991). Cultura y tradición pastoril en la montaña oriental leonesa. In L. V. Elías (Ed.), Sobre cultura pastoril (pp. 301-332). Madrid: Centro de Investigación and Animación Etnográfica.

Sánchez, A., \& Sánchez, M. C. (1986). Razas ovinas españolas. Madrid: MAPA.

Sierra, I. (2003). Evolución y cambios socioeconómicos del sector ovino-caprino en España durante la última década. Madrid: MAPA.

Urbanik, J. (2012). Placing animals: an introduction to the geography of human-animal relations. New York: Rowman and Littlefield.

Whatmore, S. (2002). Hybrid Geographies: Natures, Cultures, Spaces. London: Sage.

Whatmore, S. (2006). Materialist Returns: Practicing Cultural Geography in and for a More-Than-Human World. Cultural Geographies, 13, 600-609. https://doi.org/10.1191/1474474006cgj377oa

Williams, B., \& Riley M. (2018). The Challenge of Oral History to Environmental History. Environment and History. https://doi.org/10.3197/096734018X15254461646503

Wilson, H. (2017). On Geography and Encounter: Bodies, Borders, and Difference. Progress in Human Geography, 41, 451-471.

https://doi.org/10.1177/0309132516645958

Yarwood, R., \& Evans, N. (1998). New Places for “Old Spots": The Changing Geographies of Domestic Livestock Animals. Society and Animals, 6, 137-166.

https://doi.org/10.1163/156853098X00122 